\title{
Thermal performance characterisation of a reverse-flow energy recovery ventilator for a residential building application
}

\author{
David Hunt ${ }^{1, *}$, Naoise Mac Suibhne ${ }^{1}$, Laurentiu Dimache ${ }^{1}$, David McHugh $^{2}$, and John Lohan ${ }^{1}$ \\ ${ }^{1}$ Department of Mechanical and Industrial Engineering, Galway-Mayo Institute of Technology, Galway, Ireland. \\ ${ }^{2}$ ProAir Heat Recovery Ventilation Systems Ltd., Tuam Road, Galway, Ireland.
}

\begin{abstract}
The European Union's 2020 and 2030 sustainable energy policies seek significant reductions in both energy consumption and carbon emissions. These policies demand a greater use of energy efficient technologies and a transition away from fossil fuels. This paper studies one such technology, an indoor climate control system with a reverse-flow enthalpy recovery ventilator, capable of recovering both sensible and latent heat. The thermal performance characteristics are established using an experimental facility and calculation methods defined by European Standard EN 13141-7:2010. This involves measurement of temperature, humidity, pressure and volumetric air flow rates over a range of operating conditions. Total thermal energy recovery rates ranged from $0.63 \mathrm{~kW}$ to $2.2 \mathrm{~kW}$, with energy recovery efficiency of $72.8 \%$ to $88.6 \%$. The recovery efficiency ratio, which reflects the capacity of the indoor climate control system to recover thermal energy relative to its power consumption ranged between 6.87 to 19.97 . Due to the unique reverse-flow defrost function, the system demonstrates operation down to $-7{ }^{\circ} \mathrm{C}$ without frost formation. These results highlight the potential that this system can make towards the EU goals of reducing energy consumption, operating costs and carbon emissions associated with indoor climate control.
\end{abstract}

\section{Introduction}

The operation and maintenance of buildings account for more than $40 \%$ of global energy consumption and one third of global greenhouse gas emissions [1]. The residential and industrial building sectors' heating and cooling requirements consume $50 \%$ of Europe's annual energy [2]. To this end, policy directives at the European level such as the recast of the Energy Performance in Buildings Directive (2010/31/EU) [3], the Energy Efficiency Directive (2012/27/EU) [4] and various communications from the commission related to sustainability targets [5] underline the need to reduce building energy consumption. The need to reduce heating and cooling demands drives increased levels of thermal insulation and air tightness in the building envelope [6], [7]. Such solutions increase mechanical ventilation requirements which, although required to maintain good indoor air quality (IAQ), also reintroduces undesirable thermal losses [8], [9]. Thermal energy losses due to mechanical ventilation can be typically 35 to 40 $\mathrm{kWh} / \mathrm{m}^{2}$ year in residential buildings [10] or approximately half of the energy consumption in wellinsulated buildings [11]. Heat or energy recovery ventilation systems can significantly reduce the energy consumption of heating systems associated with space heating [12]-[14]. Guillén-Lambea et al. demonstrated that space heating and cooling requirements of nZEB energy loads cannot be achieved with current ventilation strategies in cold and mild climates, without recovering thermal energy embodied in extracted stale air [15], [16]. From a field survey of 60 units, Fehrm et al. concluded that on average mechanical ventilation systems with heat

\footnotetext{
* Corresponding author: david.hunt@,research.gmit.ie
}

recovery reduce primary energy demand by $19.4 \%$ and $\mathrm{CO}_{2}$ emissions by $18.4 \%$ [17].

Independent of building energy consumption, the role of ventilation in residential buildings is primarily to maintain good IAQ by diluting and removing air pollutants. Each year, 3.8 million premature deaths are attributed to household (indoor) air pollution [18]. IAQ is recognised as a key factor affecting public health as people spend 60 to $90 \%$ of their lives indoors [19]-[21]. However, as building quality and their energy performance improves so does the need for mechanical ventilation. For this reason, the adoption and sustainability of indoor ventilation systems must be accessed.

Interest exists in the ability of indoor climate control systems (ICCS) to reduce the energy consumption, cost and carbon emissions associated with ventilation, space heating, cooling and humidity control. This study characterises the thermal performance of an ICCS equipped with a reverse-flow energy recovery ventilator (RF-ERV). The RF-ERV combines a flat plate counterflow heat exchanger. This system also hosts a unique configuration of four motorised sliding flaps around the heat exchanger. The alternation of flap position allows the air flow direction through the heat exchanger air flow channels to be reversed. In this study, the process is referred to as energy recovery ventilation (ERV) mode. The system is described in detail, outlining several functions while focusing on ERV. An experimental setup is described to analyse the thermal performance characteristics of the full-scale ICCS device operating in ERV mode for a series of test conditions. 


\section{Principle of Operation}

Details of the ICCS under investigation are presented in Fig. 1. Fig. 1(a) shows a photo of the ICCS as configured during testing and Fig. 1(b) identifies the key components used to activate enthalpy recovery (ERV) for winter operation. Although not utilised in this study, the multifunctional ICCS combines the functionality of a RF-ERV with an air-to-air source heat pump (ASHP) that will be the focus of future work. The direct expansion coils (evaporator and condenser) of the ASHP are located in the incoming air stream $(3,8)$ on either side of the RF-ERV. Subsequently, the ICCS provides up to seven functions listed in Table 1; (1) Ventilation, (2) Heat Recovery Ventilation (HRV), (3) Energy Recovery Ventilation, (4) Space Heating, (5) Space Cooling, (6) Recirculation Space Heating and (7) Recirculation Space Cooling. The four main components are the fans $(2,9,15$ in Fig. 1), heat exchanger $(5)$, motorised flaps $(6,7,13,14)$ and heat pump. Table 1 identifies the main components used as per mode of operation and highlights the use of fans in every mode. During periods of operating in modes 2-to-7, a ductwork system is used to distribute thermally conditioned air to a building. This paper seeks to establish the thermal performance in ERV mode (3) when the ICCS is exposed to the mild/cold winter conditions generated by western Europe's Cool Marine climate [22]. The RF-ERV is an air-to-air, flat plate counter-flow heat exchanger mounted within an additional air-tight frame, that also houses four motorised sliding flaps.
The RF-ERV works on the principle of alternating the air flow direction through the heat exchanger air flow channels. The air flow can be cyclically interchanged by the four integrated motorised flaps that effectively reverse the flow direction of the air streams. The construction is shown in Fig. 2. During periods when the indoor air (IDA) temperature exceeds the outdoor air (ODA) temperature, the RF-ERV can transfer both sensible and latent heat from the outgoing stale air flow to the cooler incoming fresh air flow.

Fig. 3 illustrates the working principle of the ICCS for cold climates while in ERV mode, as it moves through several states. During the initial state (Phase 1, Fig. 3), incoming ODA passes through the upper channel and outgoing ETA through the lower channel separated by the heat exchanger wall. Water vapor in the outgoing (ETAto-EHA) air stream condenses when the heat exchangers' internal wall surface temperature equals the dew point temperature of the outgoing cooling air. The rate of condensation depends on the saturation pressure. The higher the saturation pressure the greater the rate of condensation in the heat exchanger. This generally occurs towards the cold ambient air end of the exhaust air flow channels. This is referred to as the partially wet regime. The totally wet regime occurs when condensate appears directly after the inlet to the heat exchanger, towards the warm indoor air end of the extract air flow channels [23].

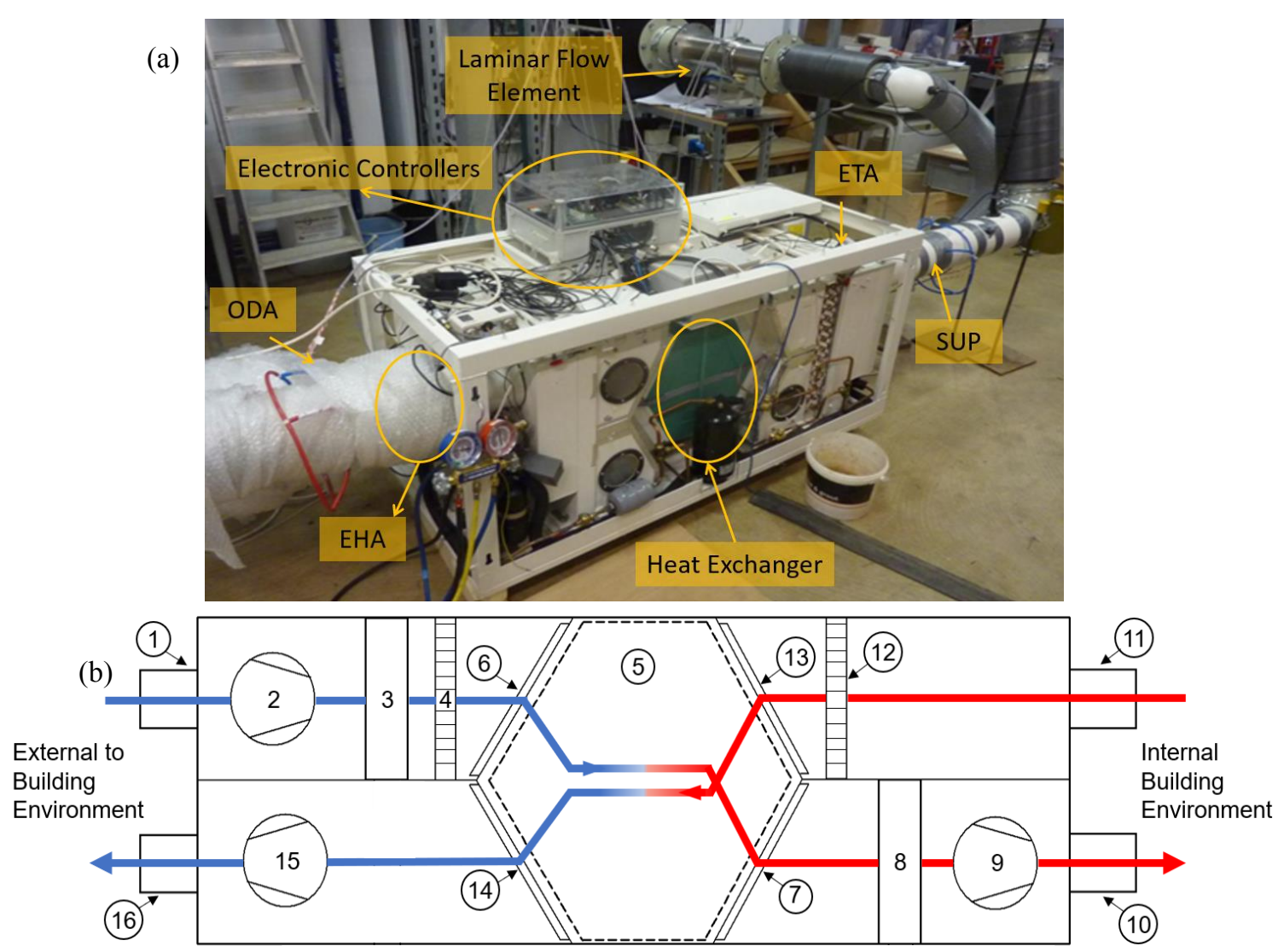

Fig. 1. A photo (a) and schematic diagram (b) of the ICCS during ERV mode for winter operation. (1) outdoor air - ODA; (2) secondary supply air fan; (3) ASHP, coil 1; (4) supply air filter; (5) heat exchanger, shown in more detail in Fig. 2; (6) ERV, motorised flap 1; (7) ERV, motorised flap 4; (8) ASHP, coil 2; (9) primary supply air fan; (10) supply air - SUP; (11) extract air - ETA; (12) extract air filter; (13) ERV, motorised flap 3; (14) ERV, motorised flap 2; (15) extract air fan; (16) exhaust air - EHA. 
Table 1. ICCS components used per operating mode.

\begin{tabular}{|c|c|c|c|c|c|}
\hline Mode of Operation & $\begin{array}{l}\text { Bypass } \\
\text { Damper }\end{array}$ & Fans & $\begin{array}{c}\text { Heat } \\
\text { Exchanger }\end{array}$ & $\begin{array}{l}\text { Motorised } \\
\text { Flaps }\end{array}$ & $\begin{array}{l}\text { Heat } \\
\text { Pump }\end{array}$ \\
\hline Ventilation (bypass heating \& cooling) & $\mathrm{X}$ & $X$ & & & \\
\hline Heat Recovery Ventilation (no moisture recovery) & & $\mathrm{X}$ & X & & \\
\hline 3* Energy Recovery Ventilation (de/humidification optional) & & $\mathrm{X}$ & $\mathrm{X}$ & $X$ & \\
\hline 4 Active Heating and Ventilation (de/humidification optional) & & $\mathrm{X}$ & $\mathrm{X}$ & $\mathrm{X}$ & $\mathrm{X}$ \\
\hline Active Cooling and Ventilation (dehumidification optional) & & $\mathrm{X}$ & $\mathrm{X}$ & $\mathrm{X}$ & $\mathrm{X}$ \\
\hline Recirculation Heating & & $\mathrm{X}$ & & $\mathrm{X}$ & $\mathrm{X}$ \\
\hline 7 Recirculation Cooling (dehumidification) & & $\mathrm{X}$ & & $\mathrm{X}$ & $\mathrm{X}$ \\
\hline
\end{tabular}

$*$ Function characterised in this study
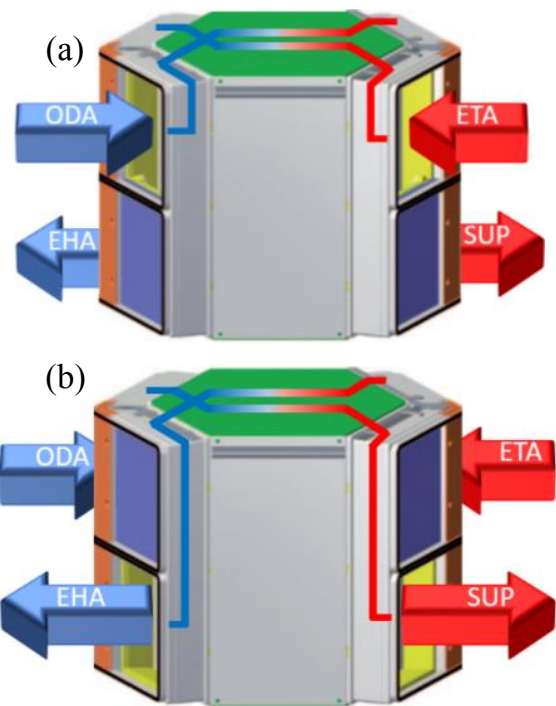

Fig. 2. Schematic representation of the RF-ERV motorised flap initial state positions (a) and final state position (b) relative to the incoming (ODA-to-SUP) and outgoing (ETA-to-EHA) air stream flow directions through the heat exchanger [24].

When the motorised flaps change position (Fig. 2, b) the flow direction through the heat exchanger is reversed (Phase 2a, Fig. 3). Incoming, cool unsaturated, fresh air now passes through the lower channel and starts to evaporate the condensate. The moisture content of the incoming air increases, while its temperature decreases, as part of the latent heat of vaporisation of the water that evaporates comes from the air. Simultaneously, moisture in the ETA, now passing through the upper channel begins to condense at the same relative position in the channel as the evaporation takes place in the adjacent channel (Phase 2b, Fig. 3). As a result, latent heat of condensation is transferred to the incoming air stream as sensible heat. Finally (Phase 2c, Fig. 3), condensate will evaporate into the incoming fresh air flow. At this state, the mirror image of the situation shown in Phase 1 is reached. Now the flaps are reactivated, and flow reversal takes place to repeat the process. If extract air (ETA) moisture content is above the predetermined indoor target, or during non-condensing conditions, the RF-ERV flap switching ends and the unit operates in HRV mode (2). This shows that, latent heat recovery is both optional and controllable.

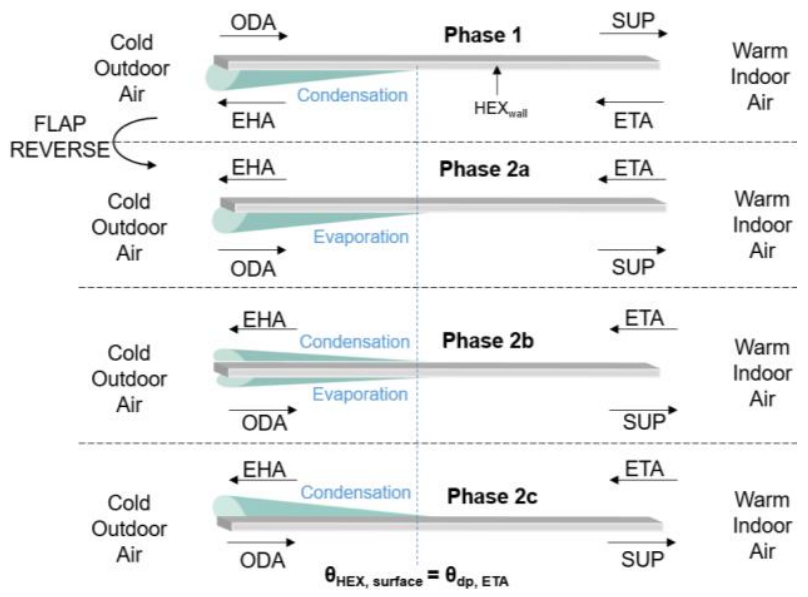

Fig. 4. Schematic representation of the RF-ERV alternation of the air flow direction through the heat exchanger channel identifying partially wet regime.

\section{Experimental Characterisation}

The test facility configuration for thermal performance characterisation is illustrated in Fig. 4. Setup required adjusting the supply $\left(\mathrm{q}_{\mathrm{v}, \mathrm{SUP}}\right)$ and extract $\left(\mathrm{q}_{\mathrm{v}, \mathrm{ETA}}\right)$ volumetric air flow rates to ensure balanced airflows within $\pm 3 \%$. This was done once at the start of the test in program, using air balancing dampers while monitoring both air flow rate and pressure measurements. Once balanced incoming/outgoing air flows was achieved all

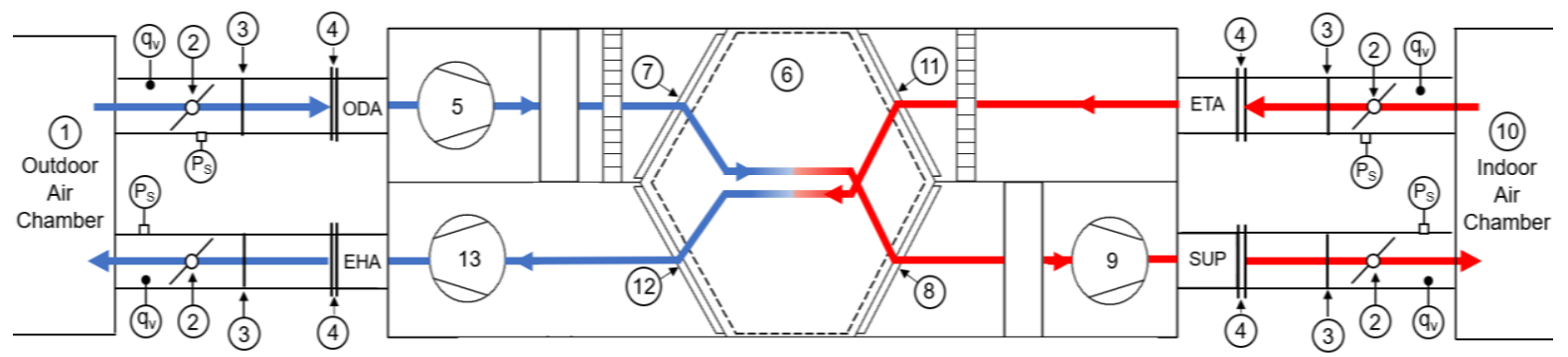

Fig. 3. Thermal test configuration for ICCS air-to-air heat exchanger. (1) outdoor air constant temperature and humidity chamber; ( $\left.\mathrm{q}_{\mathrm{v}}\right)$ volume air flow rate measurement device; (Ps) static duct pressure measurement device; (2) air balancing damper; (3) 5-point temperature and humidity measurement plane; (4) duct connection; (ODA) outdoor air; (5) secondary supply air fan; (6) heat exchanger; (7) ERV, motorised flap 1; (8) ERV, motorised flap 4; (9) primary supply air fan; (SUP) supply air: (10) indoor air constant temperature and humidity chamber (ETA) extract air; (11) ERV, motorised flap 3; (12) ERV, motorised flap 2; (13) extract air fan; (EHA) exhaust air. 
dampers were locked in position to avoid creep during temperatures (intermediate and cold test conditions), the measured mass air flow rate can drop slightly. This is due to changes in air density in the SUP and EHA streams, and so no additional airflow adjustment is required. To simulate the units recommended design for installation indoors, the ICCS ambient air temperature was maintained within $\pm 1{ }^{\circ} \mathrm{C}$ of the extract air dry bulb temperature. Static duct pressure conditions were adjusted to $100 \mathrm{~Pa}$ for both SUP and ETA ductwork to simulate typical residential building installation conditions. Both ODA and EHA static duct pressure were adjusted to $0 \mathrm{~Pa}$.

The temperature, humidity and enthalpy ratios were established by measuring the volumetric air flow rates, mean dry and wet bulb temperatures in the ODA, SUP, ETA and EHA ducts. A 5-point temperature measurement plane using PT100 resistance temperature sensors evenly distributed over the ducted cross-sections was arranged to determine the air temperature. A Furness Controls FOC96 laminar flow element, Vaisala HMP110 humidity and temperature sensor, Furness Controls FCO332 differential pressure transmitter and Yokogawa WT310E single phase power meter was used to determine the air volume flow rate, humidity, pressure and power consumption respectively. The accuracy of monitoring equipment used is presented in Table 2. Uncertainties of measurement for all test variables recorded exceeded those specified in EN 13141-7. SUP and ETA flow rates,

Table 2. Measured parameters and associated measurement accuracy.

\begin{tabular}{lll}
\hline \multirow{2}{*}{ Parameter } & \multicolumn{2}{c}{ Uncertainty of measurement } \\
& Test equipment & EN 13141 \\
\hline Air flow rate $\left[\mathrm{m}^{3} / \mathrm{h}\right]$ & $< \pm 3 \%$ & $\pm 3 \%$ \\
Dry bulb temperature $[\mathrm{K}]$ & $< \pm 0.14 \mathrm{~K}$ & $\pm 0.2 \mathrm{~K}$ \\
Wet bulb temperature $[\mathrm{K}]$ & $< \pm 0.3 \mathrm{~K}$ & $\pm 0.3 \mathrm{~K}$ \\
Air pressure $[\mathrm{Pa}]$ & $\pm 0.5 \%$ & $\pm 3 \%$ \\
Electrical power $[\mathrm{W}]$ & $< \pm 1 \%$ & $\pm 1 \%$ \\
\hline
\end{tabular}

dry and wet bulb temperature conditions for tests 1-to-8 are presented in Table 3. The RF-ERV flap switching time was set at 300 seconds and the constant volume control function was set to maintain required ventilation rates. Data was recorded every 5-seconds during all testing periods. All tests include a steady state period obtained and maintained for a minimum 30-minute duration.
Table 4. Summary of thermal test programme including ICCS operating flow rates, dry bulb (db) and wet bulb (wb) temperature conditions.

\begin{tabular}{|c|c|c|c|}
\hline Test number & $\begin{array}{c}\text { Air flow } \\
\text { rate }\left(\mathrm{m}^{3} / \mathrm{h}\right)\end{array}$ & $\begin{array}{c}\text { ODA } \\
\text { temperature }\end{array}$ & $\begin{array}{c}\text { ETA } \\
\text { temperature }\end{array}$ \\
\hline 1. Dry air & 150 & $\begin{array}{l}7^{\circ} \mathrm{C}(\mathrm{db}) \\
6^{\circ} \mathrm{C}(\mathrm{wb})\end{array}$ & $\begin{array}{l}20^{\circ} \mathrm{C}(\mathrm{db}) \\
12^{\circ} \mathrm{C}(\mathrm{wb})\end{array}$ \\
\hline 2. Dry air & 250 & $\begin{array}{l}7^{\circ} \mathrm{C}(\mathrm{db}) \\
6^{\circ} \mathrm{C}(\mathrm{wb})\end{array}$ & $\begin{array}{l}20^{\circ} \mathrm{C}(\mathrm{db}) \\
12^{\circ} \mathrm{C}(\mathrm{wb})\end{array}$ \\
\hline 3. Dry air & 350 & $\begin{array}{l}7^{\circ} \mathrm{C}(\mathrm{db}) \\
6^{\circ} \mathrm{C}(\mathrm{wb})\end{array}$ & $\begin{array}{l}20^{\circ} \mathrm{C}(\mathrm{db}) \\
12^{\circ} \mathrm{C}(\mathrm{wb})\end{array}$ \\
\hline 4. Intermediate & 150 & $\begin{array}{l}2^{\circ} \mathrm{C}(\mathrm{db}) \\
1^{\circ} \mathrm{C}(\mathrm{wb})\end{array}$ & $\begin{array}{l}20^{\circ} \mathrm{C}(\mathrm{db}) \\
12^{\circ} \mathrm{C}(\mathrm{wb})\end{array}$ \\
\hline 5. Intermediate & 250 & $\begin{array}{l}2^{\circ} \mathrm{C}(\mathrm{db}) \\
1^{\circ} \mathrm{C}(\mathrm{wb})\end{array}$ & $\begin{array}{l}20^{\circ} \mathrm{C}(\mathrm{db}) \\
12^{\circ} \mathrm{C}(\mathrm{wb})\end{array}$ \\
\hline 6. Intermediate & 350 & $\begin{array}{l}2^{\circ} \mathrm{C}(\mathrm{db}) \\
1^{\circ} \mathrm{C}(\mathrm{wb})\end{array}$ & $\begin{array}{l}20^{\circ} \mathrm{C}(\mathrm{db}) \\
12^{\circ} \mathrm{C}(\mathrm{wb})\end{array}$ \\
\hline 7. Extreme & 150 & $\begin{array}{l}-7^{\circ} \mathrm{C}(\mathrm{db}) \\
-8^{\circ} \mathrm{C}(\mathrm{wb})\end{array}$ & $\begin{array}{l}20^{\circ} \mathrm{C}(\mathrm{db}) \\
12^{\circ} \mathrm{C}(\mathrm{wb})\end{array}$ \\
\hline 8. Extreme & 250 & $\begin{array}{l}-7^{\circ} \mathrm{C}(\mathrm{db}) \\
-8^{\circ} \mathrm{C}(\mathrm{wb})\end{array}$ & $\begin{array}{l}20^{\circ} \mathrm{C}(\mathrm{db}) \\
12^{\circ} \mathrm{C}(\mathrm{wb})\end{array}$ \\
\hline
\end{tabular}

\section{Results and discussion}

Measured volumetric air flow rates and calculated enthalpy, temperature and humidity ratios for tests 1-to-8 are presented in Table 4. Both measured and calculated variables presented are averaged over the 30-minute, steady state data collection period. During the data collection period, both outdoor and indoor simulated dry and wet bulb air temperatures remained steady $\left(< \pm 0.3^{\circ} \mathrm{C}\right)$ and the supply and extract mass air flow rates balanced $(<$ $\pm 3 \%$ ).

Extreme Test 8 performed best due to the high temperature difference between the counterflows. This not only boosted sensible heat recovery to the highest value recorded $(1794.5 \mathrm{~W})$, but also precipitated the highest latent heat recovery $(424.2 \mathrm{~W})$. Such a high latent recovery is notable, since it's an order of magnitude greater than Tests 1-to-6. During Test 7 the highest recorded enthalpy $\left(\eta_{h, S U P}\right)$, temperature $\left(\eta_{\theta, S U P}\right)$ and humidity ratios $\left(\eta_{\mathrm{x}, S U P}\right)$ were $88.6 \%, 92.9 \%$ and $77.1 \%$ respectively. The influence of increased mass air flow rate on RF-ERV thermal energy recovered is significant, which results in a greater thermal energy recovered during Test 8 .

Table 3. Variables measured, thermal efficiencies calculated, and associated quantities of thermal energy recovered of experimental tests 1-to-8. Standard equation used to calculate column values are explained in the text or referenced in the column heading.

\begin{tabular}{|c|c|c|c|c|c|c|c|c|c|c|}
\hline \multirow{2}{*}{$\begin{array}{l}\text { Test number } \\
1 \text { - Dry air }\end{array}$} & \multicolumn{2}{|c|}{$\begin{array}{c}\text { Air flow rate } \\
\left(\mathrm{m}^{3} / \mathrm{h}\right) \\
\left(\mathrm{q}_{\mathrm{v}, \mathrm{sUP}}\right)\left(\mathrm{q}_{\mathrm{v}, \mathrm{ETA}}\right)\end{array}$} & \multirow{2}{*}{$\begin{array}{c}\begin{array}{c}\text { Enthalpy } \\
\text { ratio } \\
\left.\text { ( } \eta_{\mathrm{h}, \mathrm{SUP}}\right)\end{array} \\
83.4 \%\end{array}$} & \multirow{2}{*}{$\begin{array}{c}\begin{array}{c}\text { Temperature } \\
\text { ratio }[25] \\
\left(\eta_{\theta}, \mathrm{SUP}\right)\end{array} \\
92.8 \%\end{array}$} & \multirow{2}{*}{$\begin{array}{c}\begin{array}{c}\text { Humidity } \\
\text { ratio }[25] \\
\left(\eta_{\mathrm{x}, \mathrm{SUP}}\right)\end{array} \\
12.3 \%\end{array}$} & \multirow{2}{*}{$\begin{array}{c}\begin{array}{c}\text { Total energy } \\
\text { recovered [26] } \\
\left(\mathrm{Q}_{\mathrm{T}}\right)[\mathrm{W}]\end{array} \\
630.6\end{array}$} & \multicolumn{2}{|c|}{$\begin{array}{c}\text { Sensible energy } \\
\text { recovered (Qs) } \\
{[26][\mathrm{W}]}\end{array}$} & \multicolumn{2}{|c|}{$\begin{array}{c}\text { Latent energy } \\
\text { recovered (QL) } \\
{[26][\mathrm{W}]}\end{array}$} \\
\hline & 153.7 & 151.0 & & & & & 614.6 & $97.5 \%$ & 16.0 & $2.5 \%$ \\
\hline 2 - Dry air & 232.6 & 231.4 & $82.4 \%$ & $89.1 \%$ & $15.6 \%$ & 929.5 & 905.9 & $97.5 \%$ & 23.6 & $2.5 \%$ \\
\hline 3 - Dry air & 333.1 & 327.5 & $82.1 \%$ & $86.5 \%$ & $23.2 \%$ & 1303.6 & 1267.2 & $97.2 \%$ & 36.4 & $2.8 \%$ \\
\hline 4 - Intermediate & 144.2 & 147.9 & $77.4 \%$ & & & & 816.7 & & 41.6 & $4.9 \%$ \\
\hline 5 - Intermediate & 224.1 & 228.8 & $76.9 \%$ & $88.3 \%$ & $13.4 \%$ & 1275.1 & 1233.1 & $96.7 \%$ & 41.9 & $3.3 \%$ \\
\hline 6 -Intermediate & 326.3 & 330.8 & $72.8 \%$ & $86.0 \%$ & $9.8 \%$ & 1779.4 & 1725.8 & $97.0 \%$ & 53.6 & $3.0 \%$ \\
\hline 7 - Extreme & 155.9 & & $88.6 \%$ & & & & 1241.0 & & 387.0 & $23.8 \%$ \\
\hline 8 - Extreme & 220.2 & 225.6 & $80.9 \%$ & $87.8 \%$ & $60.7 \%$ & 2218.7 & 1794.5 & $80.9 \%$ & 424.2 & $19.1 \%$ \\
\hline
\end{tabular}


The calculated total, sensible and latent energies recovered were $2218.7 \mathrm{~W}, 1794.5 \mathrm{~W}$ and $424.2 \mathrm{~W}$ respectively.

The measured value for total electrical power input and calculated values for total thermal energy recovered, specific electrical power and net energy reduction during Tests 1-to- 8 are presented in Table 5 . The electrical power input is the average power consumed by the ICCS and includes both extract and supply fans, electronic controllers and four motorised flaps. The specific electrical power was calculated by dividing the total electric power input by supply volumetric air flow rate $\left(\dot{q}_{S U P}\right)$ at corresponding SUP and ETA static duct pressure of $200 \mathrm{~Pa}(100 \mathrm{~Pa}$ each). The net energy savings are calculated by subtracting the total electrical power input from the total thermal energy recovered. The recovery efficiency ratio (RER), established by dividing total thermal energy by total electrical power input is also presented.

The ability of the RF-ERV to transfer moisture contained in the outgoing air stream to the incoming air stream is presented in Fig. 5 for Test 7. The periodic rise and fall of the SUP humidity ratio results from a 300 seconds flow reversal time interval $\left(\mathrm{F}_{\mathrm{RT}}\right)$ using the motorised flaps. Under Test 7 conditions, the upper and lower humidity ratio limits are between 4.8 grams to 3.8 grams of moisture per kilogram of dry air. Fig. 5 suggest that increasing the flap switching interval will increase the
SUP humidity ratio, however, the upper limit will remain unchanged. Similarly, decreasing the flap switching interval should reduce the SUP humidity ratio, therefore reducing the lower humidity ratio. In this way the humidity of the indoor climate may be altered between these two humidity levels by varying the flow reversal time interval $\left(\mathrm{F}_{\mathrm{RT}}\right)$.

\section{Conclusion}

The aim of this paper was to investigate the thermal performance characteristics of a reverse-flow energy recovery ventilator designed for domestic indoor climate control applications. The principle of operation of the RFERV in cold climates is described. A total of eight steady state tests were conducted in a controlled test environment under various operating conditions. Ventilation rates ranged from 144.2 to $330.8 \mathrm{~m}^{3} / \mathrm{h}$, the enthalpy ratio ranged from $72.8 \%$ to $88.6 \%$, temperature ratio ranged from $86.0 \%$ to $92.9 \%$ and humidity ratio ranged from $9.8 \%$ to $77.1 \%$, respectively. Maximum recovered energy of $2218.7 \mathrm{~W}, 1794.5 \mathrm{~W}$ and $424.2 \mathrm{~W}$ for total, sensible and latent heat was calculated under Test 8 conditions, respectively, corresponding with a total electrical power input of $111.1 \mathrm{~W}$. During the sub-zero Celsius ODA Tests 7 and 8, the RF-EVR flap switching interval of 300 seconds was sufficient to avoid ice formation and therefore negates the need for frost protection unit. Subsequently, the highest recovery efficiency ratio (RER) of 19.97 was recorded under these conditions.

Table 5. Recorded electrical power input, calculation of thermal energy recovered and quantity of energy reduction of experimental tests 1-to-8. The equation used to calculation columns are described in the main text.

\begin{tabular}{lccccc}
\hline Test number & $\begin{array}{c}\text { Total thermal energy } \\
\text { recovered }[\mathrm{kW}]\end{array}$ & $\begin{array}{c}\text { Total electrical } \\
\text { power input }[\mathrm{kW}]\end{array}$ & $\begin{array}{c}\text { Specific electrical } \\
\left.\text { power [Wh/m }{ }^{3}\right]\end{array}$ & $\begin{array}{c}\text { Net energy } \\
\text { reduction [kW] }\end{array}$ & $\begin{array}{c}\text { Recovery efficiency } \\
\text { ratio [W/W] }\end{array}$ \\
\hline 1 - Dry air & 0.631 & 0.08 & 0.52 & 0.550 & 7.87 \\
2 - Dry air & 0.929 & 0.12 & 0.50 & 0.814 & 8.07 \\
3 - Dry air & 1.304 & 0.19 & 0.57 & 1.114 & 6.87 \\
4 - Intermediate & 0.858 & 0.08 & 0.53 & 0.782 & 11.18 \\
5 - Intermediate & 1.275 & 0.11 & 0.50 & 1.164 & 11.46 \\
6 - Intermediate & 1.779 & 0.19 & 0.59 & 1.587 & 9.23 \\
7 - Extreme & 1.628 & 0.08 & 0.54 & 1.545 & 19.51 \\
8 - Extreme & 2.219 & 0.11 & 0.50 & 2.108 & 19.97 \\
\hline
\end{tabular}

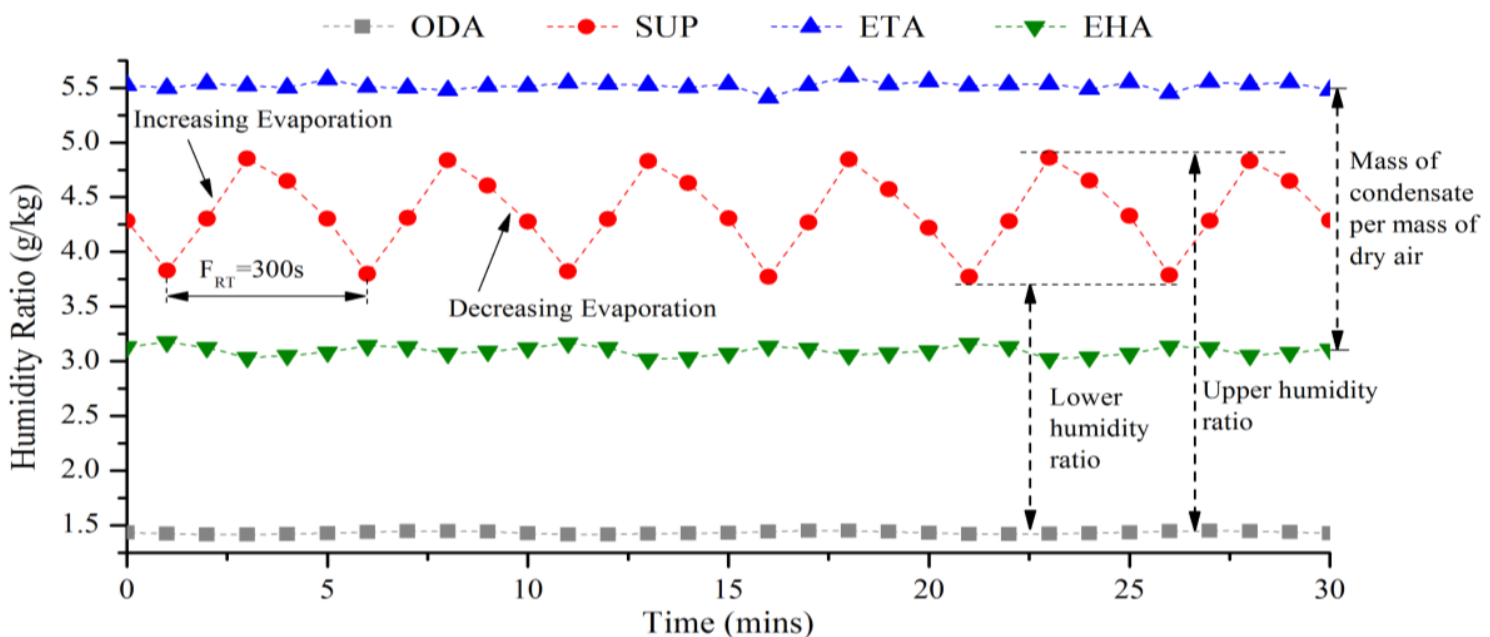

Fig. 5. Humidity ratio calculated at four duct connections during test 7 . ( $\left.\mathrm{F}_{\mathrm{RT}}\right)$ flow reversal time interval set at 300 seconds. 
The authors would like to acknowledge that this study is cofunded by the European Regional Development Fund (ERDF) under Ireland's European Structural and Investment Funds Programmes 2014-2020. This work was also collectively funded by Enterprise Ireland and ProAir Ltd. under an Innovation Partnership project: "Environment Testing of a Heat-Pump and Enthalpy Recovery Machine within an Advanced Laboratory" (E-THERMAL), under grant agreement IP/2018/0719. The experimental data was recorded in the Building Research Establishment (BRE) HVAC Engineering laboratory, Building 47, Garston, Watford, UK.

\section{References}

[1] United Nations Environment Programme, "Buildings and Climate Change," 2009.

[2] European Commission, "Towards a smart, efficient and sustainable heating and cooling sector," 2016. [Online]. Available: $\quad \mathrm{http}: / /$ europa.eu/rapid/pressrelease_MEMO-16-311_en.htm. [Accessed: 30-Dec2018].

[3] European Union, "Energy Performance of Buildings," Counc. Dir., pp. 13-35, 2010.

[4] European Parliament, "Directive 2012/27/EU of the European Parliament and of the Council of 25 October 2012 on energy efficiency," Off. J. Eur. Union Dir., no. October, pp. 1-56, 2012.

[5] European Commission, "COMMUNICATION FROM THE COMMISSION TO THE EUROPEAN PARLIAMENT, THE COUNCIL, THE EUROPEAN ECONOMIC AND SOCIAL COMMITTEE AND THE COMMITTEE OF THE REGIONS A resourceefficient Europe - Flagship initiative under the Europe 2020 Strategy," 2011. [Online]. Available: http://ec.europa.eu/eu2020/pdf. [Accessed: 30-Dec2018].

[6] C. A. Balaras, A. G. Gaglia, E. Georgopoulou, S. Mirasgedis, Y. Sarafidis, and D. P. Lalas, "European residential buildings and empirical assessment of the Hellenic building stock, energy consumption, emissions and potential energy savings," Build. Environ., vol. 42, no. 3, pp. 1298-1314, 2007.

[7] D. H. W. Li, L. Yang, and J. C. Lam, "Zero energy buildings and sustainable development implications - A review," Energy, vol. 54, pp. 1-10, 2013.

[8] Y. El Fouih, P. Stabat, P. Rivière, P. Hoang, and V. Archambault, "Adequacy of air-to-air heat recovery ventilation system applied in low energy buildings," Energy Build., vol. 54, pp. 29-39, 2012.

[9] L. Sullivan, I. Andrews, A. Christie, and C. Houghton, "Mechanical Ventilation With Heat Recovery in New Homes," no. Jan, pp. 1-13, 2012.

[10] H. Tommerup and S. Svendsen, "Energy savings in Danish residential building stock," Energy Build., vol. 38, no. 6, pp. 618-626, 2006.

[11] J. Laverge, N. Van Den Bossche, N. Heijmans, and A. Janssens, "Energy saving potential and repercussions on indoor air quality of demand controlled residential ventilation strategies," Build. Environ., vol. 46, no. 7, pp. 1497-1503, 2011.

[12] A. Y. T. Al-Zubaydi and G. Hong, "Experimental investigation of counter flow heat exchangers for energy recovery ventilation in cooling mode," Int. J. Refrig., vol. 93, pp. 132-143, 2018.

[13] M. Rasouli, C. J. Simonson, and R. W. Besant,
"Applicability and optimum control strategy of energy recovery ventilators in different climatic conditions," Energy Build., vol. 42, no. 9, pp. 1376-1385, 2010.

[14] M. Rafati Nasr, M. Kassai, G. Ge, and C. J. Simonson, "Evaluation of defrosting methods for air-to-air heat/energy exchangers on energy consumption of ventilation," Appl. Energy, vol. 151, pp. 32-40, 2015.

[15] S. Guillén-Lambea, B. Rodríguez-Soria, and J. M. Marín, "Review of European ventilation strategies to meet the cooling and heating demands of nearly zero energy buildings (nZEB)/Passivhaus. Comparison with the USA," Renew. Sustain. Energy Rev., vol. 62, pp. 561-574, 2016.

[16] S. Guillén-Lambea, B. Rodríguez-Soria, and J. M. Marín, "Evaluation of the potential energy recovery for ventilation air in dwellings in the South of Europe," Energy Build., vol. 128, pp. 384-393, 2016.

[17] M. Fehrm, W. Reiners, and M. Ungemach, "Exhaust air heat recovery in buildings," Int. J. Refrig., vol. 25, no. 4, pp. 439-449, 2002.

[18] World Health Organisation, "Household air pollution and health," 2018. [Online]. Available: http://www.who.int/news-room/fact-

sheets/detail/household-air-pollution-and-health. [Accessed: 30-Dec-2018].

[19] S. Brasche and W. Bischof, "Daily time spent indoors in German homes - Baseline data for the assessment of indoor exposure of German occupants," Int. J. Hyg. Environ. Health, vol. 208, no. 4, pp. 247-253, 2005.

[20] European Comission, "Indoor air pollution: new EU research reveals higher risks than previously thought," Eur. Com., no. September, p. IP/03/1278, 2003.

[21] N. E. Klepeis, W. C. Nelson, W. R. Ott, J. P. Robinson, A. M. Tsang, P. Switzer, J. V Behar, S. C. Hern, and W. H. Engelmann, "The National Human Activity Pattern Survey (NHAPS): a resource for assessing exposure to environmental pollutants," Nature, vol. 11, no. February, pp. 231-252, 2001.

[22] N. Burke, "An experimental characterisation of ground and air source heat pump technologies in the Irish maritime climate," Galway-Mayo Institute of Technology, 2010.

[23] S. Gendebien, S. Bertagnolio, and V. Lemort, "Investigation on a ventilation heat recovery exchanger: Modeling and experimental validation in dry and partially wet conditions," Energy Build., vol. 62, pp. 176-189, 2013.

[24] Recair, "Factsheet Recair Enthalpy," 2013.

[25] CEN, "EN 13141-7: Ventilation for buildings Performance testing of components/products for residential ventilation - Part 7: Performance testing of a mechanical supply and exhaust ventilation units (including heat recovery) for mechanical ventilation systems ," Brussels, 2010.

[26] F. P. Incropera, D. P. DeWitt, T. L. Lavine; and B. A S., Fundamentals of Heat and Mass Transfer. John Wiley \& Sons, Inc., 2007. 